\title{
Adrenal functional reserve in the full spectrum of chronic kidney disease
}

\author{
René Rodríguez-Gutiérrez ${ }^{1,2}$, José G. González-González",2, Alberto Martínez-Rodríguez³, \\ Erick Burciaga-Jiménez, ${ }^{2}$ Ricardo César Solís², Alejandro Díaz González-Colmenero², \\ Luz Adriana Ramírez-García², Sofía Mariño-Velasco² and Francisco J. Barrera-Flores² \\ ${ }^{1}$ Endocrinology Department; ${ }^{2}$ Plataforma INVEST Medicina UANL-KER Unit Mayo Clinic (KER Unit Mexico); ${ }^{3}$ Department of Internal Medicine. \\ Faculty of Medicine and Hospital Universitario "Dr. José E. González", Universidad Autónoma de Nuevo León, Monterrey, Nuevo León, Mexico
}

\begin{abstract}
Background: Altered cortisol levels have been associated with an increase in mortality and a decrease in health-related quality of life in patients with chronic kidney disease (CKD); however, adrenal response to adrenocorticotropic hormone (ACTH) stimulation test has not been evaluated in patients with stage 3a to 5 CKD with and without renal replacement therapy (RRT). Objective: To evaluate adrenal function in patients with CKD. Materials and methods: Adults with CKD underwent a low-dose cosyntropin stimulation test ( $1 \mu \mathrm{g}$ synthetic $A C T H)$, with serum cortisol levels being measured at $0,+30$ and +60 minutes posttest. Results: Sixty participants with stage 3, 4 and 5 CKD (with and without RRT) were included. None of the patients had adrenal insufficiency (Al). The correlation observed between cortisol concentration at baseline and 30 minutes and 1 hour after stimulation and glomerular filtration rate (GFR) was negative and statistically significant ( $r:-0.39$ [p $=0.002], r:-0.363$ $[p=0.004], r:-0.4$ [ $p=0.002]$, respectively). Conclusion: Since CKD early stages, cortisol levels increase as GFR decreases. Therefore, we conclude that systematic screening for Al is not necessary in CKD patients.
\end{abstract}

KEY WORDS: Cortisol. Adrenal insufficiency Chronic kidney disease.

\section{Reserva funcional adrenal en el espectro completo de la enfermedad renal crónica}

\section{Resumen}

Antecedentes: Niveles alterados de cortisol se han asociado a un incremento en la mortalidad y disminución en la calidad de vida en pacientes con enfermedad renal crónica (ERC), sin embargo, la respuesta adrenal a la prueba de estimulación con adrenocorticotropina $(A C T H)$ no ha sido evaluada en pacientes con ERC etapas 3a a 5 con y sin terapia de reemplazo renal (TRR). Objetivo: Evaluar la función adrenal de pacientes con ERC. Materiales y métodos: Adultos con ERC se sometieron a una prueba de estimulación con cosintropina a dosis baja (1 $\mathrm{\mu g}$ de ACTH sintética) y se midieron los niveles séricos de cortisol a los $0,+30$ y +60 minutos postestimulación. Resultados: 60 participantes con ERC en etapas 3,4 y 5 (con y sin TRR) fueron incluidos. Ninguno de los pacientes presentó insuficiencia adrenal (IA). La correlación observada entre la concentración basal, a los 30 minutos y 1 hora de cortisol postestimulación y la tasa de filtrado glomerular (TFG) fue negativa y estadísticamente significativa ( $r:-0.39$ [p $=0.002], r:-0.363$ [ $p=0.004], r:-0.4[p=0.002]$, respectivamente). Conclusión: Desde etapas tempranas de la ERC los niveles de cortisol se incrementan a medida que la TFG disminuye. Concluimos que no es necesario un tamizaje sistemático para detectar IA en pacientes con ERC.

PALABRAS CLAVE: Cortisol. Insuficiencia adrenal. Enfermedad renal crónica.

\footnotetext{
Correspondencia:

Fecha de recepción: 14-07-2021

*René Rodríguez-Gutiérrez

Fecha de aceptación: 12-08-2021

E-mail: rodriguezgutierrez.rene @mayo.edu

DOI: 10.24875/GMM.M21000605

Gac Med Mex. 2021;157:502-507

Contents available at PubMed license (http://creativecommons.org/licenses/by-nc-nd/4.0/).
} 


\section{Introduction}

Chronic kidney disease (CKD) is one of the most prevalent and devastating chronic health conditions due to an associated decrease in quality of life, and increased morbidity and mortality. ${ }^{1,2}$ CKD patients have been described to have alterations in the pituitary-adrenal axis $^{3-5}$ that cause hormonal imbalances. In fact, aldosterone and cortisol levels imbalance has been associated with an increase in mortality and a decrease in health-related quality of life in patients with CKD. ${ }^{5-7}$

Symptoms and metabolic alterations present both in CKD and adrenal dysfunction may overlap. In addition, in the context of CKD and other comorbidities, adrenal insufficiency (Al) could be underdiagnosed, even by experienced physicians.

Previous studies have shown that patients with end-stage CKD have normal to high cortisol levels after a stimulation test with cosyntropin at doses ranging from $1 \mu \mathrm{g}$ (low dose) to $250 \mu \mathrm{g}$ (standard dose). However, these studies focused on patients undergoing renal replacement therapy (RRT), included small samples and the cosyntropin doses

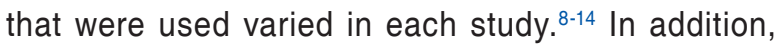
adrenal functional reserve has not been studied in patients with stage $3 a$ to 5 CKD with and without RRT.

For this reason, we decided to assess adrenal function in patients covering the full spectrum of CKD using a low-dose cosyntropin stimulation test.

\section{Materials and methods}

\section{Participants}

Adults with a previous diagnosis of stage $3 a$ to 5 CKD according to KDIGO (Kidney Disease: Improving Global Outcomes) criteria were consecutively recruited..$^{15}$ Depending on glomerular filtration rate (GFR), estimated using the CKD-EPI equation, ${ }^{16}$ participants were divided into four groups: a) stage $3, b$ ) stage 4, c) stage 5 without RRT, and d) stage 5 with RRT.

Patients with a history of acute infectious disease within the previous six months, oncological or thyroid disease, as well as patients taking medications that alter the pituitary-adrenal axis, were excluded. The study protocol was approved by the Research Ethics Committee of Autonomous University of Nuevo León
"Dr. José E. González" Hospital, and informed consent was obtained from all participants.

\section{Study protocol}

After obtaining a thorough medical history and confirming a fasting period of at least eight hours, $1 \mu \mathrm{g}$ of synthetic adrenocorticotropin (ACTH) (Cortrosyn ${ }^{\circledR}$, Amphastar Pharmaceuticals Inc., Rancho Cucamonga, CA, USA) was administered as a bolus, and blood samples were obtained at 0,30 and 60 minutes post-test in order to measure serum cortisol levels.

Adrenal insufficiency (Al) was defined as a cortisol peak lower than $496 \mathrm{nmol} / \mathrm{L}$ at 30 or 60 minutes post-stimulation.

\section{Measurements}

Cortisol concentration was measured by electro-chemiluminescence using the Cobas $^{\circledR}$ e-411 analyzer with the corresponding Roche commercial kit (Roche, SA de CV). Intra-test and inter-test coefficient of variation was 1.23 and $1.57 \%$, respectively. All blood samples were centrifuged and stored at $-20{ }^{\circ} \mathrm{C}$ for subsequent simultaneous analysis.

\section{Statistical analysis}

The sample size was calculated taking into account a difference of $8.6 \mu \mathrm{g} / \mathrm{dL}$ between cortisol mean peaks of patients with CKD on RRT and patients with CKD without RRT. ${ }^{12}$ To achieve a statistical power of $80 \%$, at least 12 patients from each CKD category were estimated to be required. Central tendency and dispersion measures were used for numerical variables, and frequencies and percentages for categorical variables. Parametric and non-parametric numerical variables between-group comparisons were obtained using ANOVA and Kruskal-Wallis test, respectively. Post hoc analyses were conducted using Bonferroni's correction. Pearson's chi-square test was used for categorical variables. Pearson's correlation coefficient was used to evaluate the correlation between GFR and serum cortisol concentration. A Pearson coefficient $>0.5$ was established as evidence of a moderately strong linear correlation. A p-value $<0.05$ was considered statistically significant. The analysis was performed using IBM SPSS Statistics v25 software (IBM 2019). 
Gaceta Médica de México. 2021;157

Table 1. Baseline characteristics of patients with CKD at different stages

\begin{tabular}{|c|c|c|c|c|c|}
\hline & Stage 3 & Stage 4 & Stage 5 without RRT & Stage 5 with RRT & p-value \\
\hline Age & $58(9.6)$ & $55.2(8.2)$ & $52.4(8.7)$ & $51.8(15)$ & 0.36 \\
\hline Female gender & $9(60)$ & $5(33.3)$ & $6(40)$ & $7(46.7)$ & 0.5 \\
\hline Creatinine & $1.6(.42)$ & $3(.57)$ & $6.2(2.3)$ & $7.3(3.3)$ & $<0.001$ \\
\hline GFR & $39(7.8)$ & $21(4.2)$ & $9.8(3.9)$ & $8(3.3)$ & $<0.001$ \\
\hline Months with CKD & $12(6-36)$ & $12(8-24)$ & $12(7-24)$ & $24(12-72)$ & 0.37 \\
\hline Weight & $75(15)$ & $79.4(21.5)$ & $76(15)$ & $71.2(21.6)$ & 0.6 \\
\hline BMI & $30(6.1)$ & $29.5(5.9)$ & $29.2(6.9)$ & $26.8(6.5)$ & 0.53 \\
\hline Systolic blood pressure & $144(12.6)$ & $136(23)$ & $133.8(25.3)$ & $148.4(20.3)$ & 0.2 \\
\hline Diastolic blood pressure & $77.5(10.3)$ & $73.6(1)$ & $75.7(14.9)$ & $82.2(15.7)$ & 0.3 \\
\hline Hypertension & $15(100)$ & 14 (93.3) & $15(100)$ & $15(100)$ & 0.3 \\
\hline Diabetes mellitus & $11(73.3)$ & $11(73.3)$ & $13(86.7)$ & $14(93.3)$ & 0.3 \\
\hline Dyslipidemia & $11(73.3)$ & $4(26.7)$ & $3(20)$ & $5(33.3)$ & 0.01 \\
\hline Acute myocardial infarction & $1(6.7)$ & $1(6.7)$ & $1(6.7)$ & $1(6.7)$ & 1 \\
\hline Cerebrovascular event & $4(26.7)$ & $2(13.3)$ & $1(6.7)$ & 0 & 0.12 \\
\hline Heart failure & $4(26.7)$ & $2(13.3)$ & $1(6.7)$ & $1(6.7)$ & 0.32 \\
\hline Antihypertensive drugs & $15(100)$ & 14 (93.3) & $15(100)$ & $15(100)$ & 0.38 \\
\hline Glucose-lowering drugs & $3(20)$ & $1(6.7)$ & $1(6.7)$ & $1(6.7)$ & 0.52 \\
\hline Insulin & $8(53.3)$ & $9(60)$ & $10(66.7)$ & $8(53.3)$ & 0.86 \\
\hline Aspirin & $3(20)$ & $3(20)$ & $2(13.3)$ & $1(6.7)$ & 0.69 \\
\hline Statins & $12(80)$ & $10(66.7)$ & $8(53.3)$ & $2(13.3)$ & 0.002 \\
\hline Fibrates & $1(6.7)$ & $2(13.3)$ & 0 & $1(6.7)$ & 0.54 \\
\hline Diuretics & $9(60)$ & $12(80)$ & $10(66.7)$ & $5(33.3)$ & 0.06 \\
\hline Hemoglobin & $11.6(1.5)$ & $11.1(1.7)$ & $9.8(1.3)$ & $9.8(2.53)$ & 0.014 \\
\hline White blood cell count & $8.3(2.5)$ & $7.4(1.7)$ & $7.3(1.3)$ & $7.8(2.8)$ & 0.63 \\
\hline Neutrophils & $5.1(2.5)$ & $4.3(1.2)$ & $4.7(1.1)$ & $5.5(2.3)$ & 0.36 \\
\hline Lymphocytes & $2.2(.5)$ & $2.2(.8)$ & $1.6(.6)$ & $1.4(.6)$ & 0.001 \\
\hline Platelets & $240.80(64.79)$ & $235.86(57.68)$ & $218.53(56.72)$ & $194.6(99.7)$ & 0.29 \\
\hline Blood urea nitrogen & $25.20(14.71)$ & $40.13(15.09)$ & $64.16(22.66)$ & $38.51(16.69)$ & $<0.001$ \\
\hline Glucose & $107(93-138)$ & $116(90-131)$ & $111(101-127)$ & $136(107-159)$ & 0.25 \\
\hline Sodium & $138.4(3.1)$ & $137.3(4.4)$ & $137.3(4)$ & $135.3(5.5)$ & 0.27 \\
\hline Chlorine & $104.6(4.9)$ & $106.6(3.6)$ & $106.2(5.9)$ & $97.6(5.7)$ & $<0.001$ \\
\hline Potassium & $4.5(.6)$ & $4.7(.7)$ & $4.8(.7)$ & $4(.6)$ & 0.007 \\
\hline Calcium & $8.7(.4)$ & $8.6(.7)$ & $8.2(.5)$ & $8.7(1.3)$ & 0.34 \\
\hline
\end{tabular}

Measurements expressed as frequencies (\%), mean (standard deviation) or median (interquartile range). CKD: chronic kidney disease; RRT: renal replacement therapy; GFR: glomerular filtration rate. 
Table 2. Cortisol values (nmol/L) before and after administration of $1 \mu \mathrm{g}$ of Cortrosyn ${ }^{\circledR}$

\begin{tabular}{|l|c|c|c|c|c|}
\hline & Stage 3 & Stage 4 & Stage 5 without RRT & Stage 5 with RRT & p-value \\
\hline Baseline cortisol & $418.2(121.8)$ & $469(124)$ & $594.2(301.1)$ & $590.6(228)$ & 0.05 \\
\hline Cortisol at 30 minutes & $825.6(165.3)$ & $828.4(98)$ & $957.1(305)$ & $971(201.8)$ & 0.09 \\
\hline Cortisol at 1 hour & $895.6(157.1)$ & $931.5(164.4)$ & $1083(342.6)$ & $1112.1(221.5)$ & 0.03 \\
\hline Peak & $915.3(164.8)$ & $943.2(146.7)$ & $1083(342.6)$ & $1112.1(221.5)$ & 0.05 \\
\hline Cortisol delta & $497(160.3)$ & $474.2(140.5)$ & $488.7(163.7)$ & $521.4(116.4)$ & 0.84 \\
\hline
\end{tabular}

Values expressed as the mean (standard deviation).

RRT: renal replacement therapy.

Table 3. Cortisol values (nmol/L) before and after administration of $1 \mu \mathrm{g}$ of Cortrosyn ${ }^{\circledast}$ in 3 groups

\begin{tabular}{|l|c|c|c|c|}
\hline & $\begin{array}{c}\text { Stage 3 } \\
(\mathbf{n = 1 5})\end{array}$ & $\begin{array}{c}\text { Stage 4 } \\
(\mathbf{n = 1 5})\end{array}$ & $\begin{array}{c}\text { Stage 5 with and without RRT } \\
(\mathbf{n}=30)\end{array}$ & $\begin{array}{c}\text { p-value } \\
\text { Baseline cortisol }\end{array}$ \\
\hline Cortisol at 30 minutes & $418.2(121.8)$ & $469(124)$ & $592.4(262.4)$ & 0.021 \\
\hline Cortisol at 1 hour & $825.6(165.3)$ & $828.4(98)$ & $964.1(254.2)$ & 0.042 \\
\hline Peak & $895.6(157.1)$ & $931.5(164.4)$ & $1097.5(283.8)$ & 0.012 \\
\hline Cortisol delta & $915.3(164.8)$ & $943.2(146.7)$ & $1097.5(283.8)$ & 0.022 \\
\hline
\end{tabular}

Values expressed as the mean (standard deviation).

RRT: renal replacement therapy.

\section{Results}

A total of 60 patients with CKD were included (15 in each group). Baseline characteristics are shown in table 1.

\section{Prevalence of adrenal insufficiency and serum cortisol comparison}

None of the included patients showed AI (Table 2). However, a significant difference was found in plasma cortisol concentration at 60 minutes post-stimulation between all four groups $(p=0.03)$. A trend towards an increase in baseline cortisol levels was observed across all different CKD categories. When stage 5 patients (with and without RRT) were analyzed as a single group, we observed a statistically significant difference in cortisol peaks $(p=0.02)$, and in baseline concentration $(p=0.02)$, and at $30(p=0.042)$ and 60 minutes $(p=0.012)$ between the three groups (Table 3). The correlation observed between cortisol baseline concentration, at 30 minutes and 1 hour post-stimulation and GFR was negative and statistically significant $(r:-0.39$ [ $p=0.002], r:-0.363$ [ $p=0.004]$, $r:-0.4[p=0.002]$, respectively).
Table 4 shows baseline and post-stimulation cortisol levels according to blood urea nitrogen serum levels.

\section{Discussion}

Previous literature had focused on the relationship between cortisol levels and GFR rather than with the incidence of $\mathrm{Al}$ in patients with CKD. ${ }^{8-14}$ In our study, no participant met the criteria for $\mathrm{Al}$ in response to the stimulation test with low-dose cosyntropin $(1 \mu \mathrm{g}) .^{17}$ However, we found significant differences between the different CKD groups (stages 3, 4 and 5 with and without RRT) in baseline cortisol levels and at 30 and 60 minutes post-stimulation.

The prevalence of $\mathrm{Al}$ in patients on RRT who had hypotension was $26 \%$ in studies where salivary cortisol was measured. ${ }^{18-20}$ In our study, the absence of Al might be explained by the lack of patients with hypotension and by serum cortisol measurement. For this reason, it would be valuable to evaluate the concordance between serum and salivary cortisol levels in patients with CKD in order to validate the use of this method as a screening test for $\mathrm{Al}^{21}$

Cortisol levels are expected to increase in stressful situations such as $\mathrm{CKD},{ }^{22}$ which could be explained by 
Table 4. Cortisol values (nmol/L) before and after administration of $1 \mu \mathrm{g}$ of Cortrosyn ${ }^{\circledast}$ in groups divided according to blood urea nitrogen level ${ }^{*}$

\begin{tabular}{|l|c|c|c|}
\hline & $<60$ & $>60$ & p-value \\
\hline Baseline cortisol & $479.8(167.4)$ & $688.3(321.7)$ & 0.01 \\
\hline Cortisol at 30 minutes & $876.1(180.2)$ & $1022.4(299.4)$ & 0.84 \\
\hline Cortisol at 1 hour & $971.6(198.5)$ & $1156.7(371.4)$ & 0.04 \\
\hline Peak & $981.2(193.3)$ & $1156.7(371.4)$ & 0.033 \\
\hline Cortisol delta & $501.4(138)$ & $468.3(171.5)$ & 0.46 \\
\hline
\end{tabular}

Values expressed as the mean (standard deviation).

a decrease in renal clearance and by 11-beta-hydroxysteroid dehydrogenase type 2 inactivity. ${ }^{23}$ However, studies in which patients with CKD and healthy controls were included did not find statistically significant differences between salivary cortisol levels. ${ }^{9,14,18}$ Our results show that, since CKD early stages, cortisol concentration increased as GFR decreased, which had not been previously reported. These findings suggest a protective effect against $\mathrm{Al}$ at CKD terminal stages. ${ }^{8-14}$

The strengths of our study include the use of a superior sample of patients belonging to CKD full spectrum with few demographic and biochemical differences between all four groups, none of which has been previously associated with adrenal gland dysfunction. ${ }^{24}$ As a limitation, most our patients had diabetes and were relatively young (50-55 years).

\section{Conclusions}

Our results suggest that adrenal function evaluation is not necessary in patients with CKD. A negative correlation was observed between serum cortisol levels and GFR; however, further studies are required in order for the clinical significance of this association to be clarified.

\section{Acknowledgments}

The authors thank Tomás Alvarado Peña, Patricio Guillermo García Espinoza, Rodolfo Alan Aguilar Torres and Edgar Botello Hernández for their valuable participation in the study.

\section{Funding}

This work was financed with Universidad Autónoma de Nuevo León "Dr. José E. González" University Hospital Endocrinology Department own resources.

\section{Conflict of interests}

The authors declare that they have no conflicts of interest.

\section{Ethical disclosures}

Protection of human and animal subjects. The authors declare that the procedures that were followed adhered to the ethical standards of the responsible committee for experimentation on human beings and were in agreement with the World Medical Association and the Declaration of Helsinki.

Confidentiality of data. The authors declare that they have followed the protocols of their work center on the publication of patient data.

Right to privacy and informed consent. The authors have obtained informed consent from the patients and/or subjects referred to in the article. This document is in the possession of the corresponding author.

\section{References}

1. Hill NR, Fatoba ST, Oke JL, Hirst JA, Callaghan AO, Lasserson DS, et al. Global prevalence of chronic kidney disease - A systematic review and meta-analysis. PLoS One. 2016;11(7):1-18.

2. GBD Chronic Kidney Disease Collaboration. Global, regional, and national burden of chronic kidney disease, 1990-2017: a systematic analysis for the Global Burden of Disease Study 2017. Lancet. 2020;395(10225):709-33.

3. Belarbia A, Nouira S, Sahtout W, Guedri Y, Achour A. Aldosterone renin ratio and chronic kidney disease. Saudi J Kidney Dis Transplant. 2015;26(5):931-40.

4. Asao T, Oki K, Yoneda M, Tanaka J, Kohno N. Hypothalamic-pituitary-adrenal axis activity is associated with the prevalence of chronic kidney disease in diabetic patients. Endocr J. 2016;63(2):119-26.

5. Meuwese CL, Carrero JJ. Chronic kidney disease and hypothalamic-pituitary axis dysfunction: The chicken or the egg? Arch Med Res. 2013;44(8):591-600.

6. Drechsler C, Ritz E, Tomaschitz A, Pilz S, Schönfeld S, Blouin K, et al. Aldosterone and cortisol affect the risk of sudden cardiac death in haemodialysis patients. Eur Heart J. 2013;34(8):578-85.

7. Ros S, Carrero JJ. Endocrine alterations and cardiovascular risk in CKD: Is there a link? Nefrologia. 2013;33(2):181-7.

8. Clodi M, Riedl M, Schmaldienst S, Vychytil A, Kotzmann H, Kaider A, et al. Adrenal function in patients with chronic renal failure. Am J Kidney Dis. 1998:32(1):52-5.

9. Grekas D, Tourkantonis A, Pharmakiotis A. Adrenal responsiveness during and after intermittent hemodialysis. Clin Exp Dial Apheresis. 1983;7(3):197-205.

10. McDonald WJ, Golper TA, Mass RD, Kendall JW, Porter GA, Girard DE, et al. Adrenocorticotropin-cortisol axis abnormalities in hemodialysis patients. J Clin Endocrinol Metab. 1979;48(1):92-5.

11. Ramírez G. Evaluation of the hypothalamic hypophyseal adrenal axis in patients receiving long-term hemodialysis. Arch Intern Med. 1982;142(8):1448-52.

12. Siamopoulos KC, Dardamanis M, Kyriaki D, Pappas M, Sferopoulos G, Alevisou V. Pituitary adrenal responsiveness to corticotropin-releasing hormone in chronic uremic patients. Perit Dial Int. 1990;10(2):153-6.

13. Siamopoulos KC, Eleftheriades EG, Pappas M, Sferopoulos G, Tsolas O. Ovine corticotropin-releasing hormone stimulation test in patients with chronic renal failure: Pharmacokinetic properties, and plasma adrenocorticotropic hormone and serum cortisol responses. Horm Res Paediatr. 1988;30:17-21.

14. Luger A, Lang I, Kovarik J, Stummvoll HK, Templ H. Abnormalities in the hypothalamic-pituitary-adrenocortical axis in patients with chronic renal failure. Am J Kidney Dis. 1987;9(1):51-4. 
15. Kidney Disease: Improving Global Outcomes (KDIGO) CKD Work Group. KDIGO 2012 Clinical Practice Guideline for the Evaluation and Management of Chronic Kidney Disease. Kidney Int Suppl. 2013;3(1).

16. Levey AS, Stevens LA, Schmid CH, Zhang Y, Castro III AF, Feldman HI, et al. A new equation to estimate glomerular filtration rate. Ann Intern Med. 2009;150(9):604-12.

17. Bornstein SR, Allolio B, Arlt W, Barthel A, Don-Wauchope A, Hammer $\mathrm{GD}$, et al. Diagnosis and treatment of primary adrenal insufficiency: An endocrine society clinical practice guideline. J Clin Endocrinol Metab. 2016;101(2):364-89.

18. Arregger AL, Cardoso EML, Zucchini A, Aguirre EC, Elbert A, Contreras $\mathrm{LN}$. Adrenocortical function in hypotensive patients with end stage renal disease. Steroids. 2014;84:57-63.

19. Arregger AL, Cardoso EML, Tumilasci O, Contreras LN. Diagnostic value of salivary cortisol in end stage renal disease. Steroids. 2008;73(1):77-82.
20. Harvey CJ, Gower PE, Hawkins PN, Pepys MB, Phillips ME. Occult adrenal insufficiency secondary to amyloidosis in the context of chronic renal failure. Nephrol Dial Transplant. 1995;10(7):1237-9.

21. Bastin P, Maiter D, Gruson D. Salivary cortisol testing: Preanalytic and analytic aspects. Ann Biol Clin (Paris). 2018;76(4):393-405

22. Elbuken G, Karaca Z, Tanriverdi F, Unluhizarci K, Kelestimur F. Assessment of the hypothalamic-pituitary-adrenal axis in critical illness. Expert Rev Endocrinol Metab. 2011;6(1):35-48.

23. N'Gankam V, Uehlinger D, Dick B, Frey BM, Frey FJ. Increased cortisol metabolites and reduced activity of $11 \beta$-hydroxysteroid dehydrogenase in patients on hemodialysis. Kidney Int. 2002;61(5):1859-66.

24. Mazziotti G, Formenti AM, Frara S, Roca E, Mortini P, Berruti A, et al. Management of endocrine disease risk of overtreatment in patients with adrenal insufficiency: Current and emerging aspects. Eur $\mathrm{J}$ Endocrinol. 2017;177(5):R231-48. 